\title{
CACAT HUKUM DALAM HIBAH SEBAGAI PERJANJIAN SEPIHAK DAN IMPLIKASINYA
}

\author{
Nila Manda Sari, Yunanto \\ Program Studi Magister Kenotariatan, \\ Fakultas Hukum, Universitas Diponegoro
}

\begin{abstract}
Grant Agreement in the modern era has been regarded as a normal thing, but most of the implementations found incorrect according to legislation. The method used in this research is juridical empirical, specification of this research is descriptive. Deed of grant can be canceled after the grant was not carried out as required, that is done by notary deed pursuant to Article 1682 joint 1683 of the Civil Code. Then if the donated goods are not the property of the grantor in violation of the provisions of Article 200 Compilation of Islamic law is an act which is done in the framework of the delivery of goods / items from the grantor to the grantee and the goods delivered are the properties of their own. Then, if the grantor proved to have died when the deed of grant was made contrary to the provisions of Article 1666 of the Civil Code clearly confirms that the grant is an agreement by who provides grants, at the time of his life, freely and irrevocably, handed some object for the purposes of the grant recipient to take advantage of it. Then grant that exceed 1/3 of his property contrary to the provisions of Article 210 paragraph (2) Compilation of Islamic Law. As a result the consequences of legal defect for internal party and the third party of the cancellation of the deed of grant ownership of the property / land will be returned to the grantor / owner of the land.
\end{abstract}

Keywords : Agreement Cancellation, Grant Agreement, Legal Defect in Grant

\begin{abstract}
Abstrak
Pembuatan Perjanjian Hibah di era modern sudah dianggap sebagai hal yang lumrah, akan tetapi dalam implementasinya banyak pembuatan perjanjian hibah tidak sesuai dengan peraturan perundang-undangan yang berlaku. Metode pendekatan yang digunakan dalam penelitian ini adalah yuridis empiris, spesifikasi penelitian ini adalah deskriptif analitis. Pemberian hibah sebagai perjanjian sepihak terjadi cacat hukum jika hal tersebut tidak dengan akta Notaris berdasarkan ketentuan Pasal 1682 jo 1683 KUHPerdata. Apabila barang yang dihibahkan bukan barang milik pemberi hibah, melanggar ketentuan Pasal 200 Kompilasi Hukum Islam yaitu suatu perbuatan yang dilakukan dalam rangka penyerahan suatu barang/benda dari pemberi hibah kepada penerima hibah dan barang yang diserahkan tersebut adalah barang milik sendiri. Kemudian apabila si pemberi hibah terbukti sudah meninggal dunia ketika akta hibah dibuat, bertentangan dengan ketentuan Pasal 1666 KUHPerdata menegaskan bahwa
\end{abstract}


hibah adalah suatu perjanjian dengan mana si penghibah, di waktu hidupnya, dengan cuma-cuma dan dengan tidak dapat ditarik kembali, menyerahkan sesuatu benda guna keperluan si penerima hibah yang menerima penyerahan itu. Kemudian pengibahan yang melebihi 1/3 harta bendanya bertentangan dengan ketentuan Pasal 210 ayat (2) Kompilasi Hukum Islam. Implikasi dari akta hibah yang cacat hukum bagi pihak interrnal dan pihak ketiga adalah kepemilikan atas harta/tanah tersebut akan kembali kepada pemberi hibah/pemilik tanah.

Kata kunci : Pembatalan Akta, Perjanjian Hibah, Cacat Hukum Hibah

\section{A. Pendahuluan}

Manusia merupakan makhluk sosial yang tidak dapat hidup sendiri tanpa bantuan orang lain. Walaupun dalam kenyataannya manusia hidup individual dikarenakan urusan dan kesibukan mereka masing-masing, tetap menjadi kodrat manusia sebagai makhluk sosial. Sehingga di dalam kehidupan bermasyarakat manusia selalu membutuhkan antara satu dengan yang lain.

Manusia dalam perannya sebagai makhluk sosial adalah makhluk yang selalu memiliki keinginan dan kebutuhan untuk bermasyarakat dan bersosialisasi dengan sesamanya. Di dalam menjalin hubungan antara sesama manusia yang satu dengan yang lain, biasanya masing-masing pihak ingin mempertahankan kepentingan yang berbeda, adakalanya kepentingan mereka bertentangan sehingga dapat menimbulkan perselisihan di antara beberapa pihak. Salah satu contoh interaksi sosial dalam kehidupan bermasyarakat manusia adalah hibah, dan sama seperti bentuk interaksi sosial manusia lain, dalam pelaksanaanya, hibah diatur oleh hukum dan peraturan yang berlaku.

Hibah merupakan suatu pemberian secara cuma-cuma ataupun suatu bentuk hadiah kepada seseorang. Pemberian hibah dilaksanakan sebagai fungsi sosial dalam masyarakat, sehingga masalah-masalah pewarisan tanah dapat diselesaikan melalui hibah, tetapi kenyataannya hibah bukan merupakan solusi yang tepat terhadap permasalahan-permasalahan tanah. Pengertian hibah diatur dalam Pasal 1666 KUHPerdata yang berbunyi: "Hibah adalah suatu perjanjian dengan mana si penghibah, di waktu hidupnya, dengan cuma-cuma dan dengan tidak dapat ditarik 
kembali, menyerahkan sesuatu benda guna keperluan si penerima hibah yang menerima penyerahan itu.".

Dalam hibah terdapat karakter yang bersifat sepihak, hanya si pemberi hibah saja yang dibebani dengan kewajiban-kewajiban, sedang penerima hibah, sama sekali tidak mempunyai kewajiban apa apa sebagai tegen prestasi. Permasalahanpermasalahan hukum timbul atas hibah cacat hukum karena sifat hibah sebagai perjanjian sepihak. Untuk hibah yang cacat hukum karena telah melanggar ketentuan dan aturan hukum maka akibat dan konsekuensinya adalah hibah tersebut harus batal demi hukum sepanjang dapat dibuktikan telah melanggar aturan Hukum. Hibah cacat hukum walaupun secara hukum harus batal demi hukum namun untuk gugatan-gugatan yang banyak terjadi atas pelaksanaan hibah maka majelis hakim harus memutus perkara secara arif dan bijaksana sehingga putusan yang dijatuhkan betul-betul menjadi rasa keadilan, bermanfaat dan adanya kepastian hukum terhadap perkara yang diajukan tersebut.

Undang-undang tidak mengakui lain-lain hibah selain hibah di antara orangorang yang masih hidup (Pasal 1666 ayat (2) KUHPerdata). Secara sederhana, hibah dapat diartikan sebagai pemberian sebagian atau seluruh dari harta kekayaan seseorang kepada orang lain sewaktu masih hidup dan peralihan hak dari pemberi hibah kepada penerima hibah sudah berlangsung seketika itu juga.(Amanat, 2003)

Dari bunyi Pasal 1666 KUHPerdata mengenai hibah terdapat kata-kata "tidak dapat ditarik kembali" ini tidak berarti bahwa penghibahan tidak dapat ditarik kembali oleh si penghibah dengan tiada izin pihak lain, oleh karena tiap tiap persetujuan hanya dapat ditarik kembali dengan kemauan kedua belah pihak (Pasal 1338 ayat 2 KUHPerdata). Oleh karenanya hibah termasuk ke dalam perjanjian sepihak yaitu perjanjian yang membebankan prestasi hanya pada satu pihak.

Timbulnya sengketa dalam hibah dapat terjadi apabila ada pihak yang merasa dirugikan. Pihak yang dirugikan misalnya pihak yang merasa ikut memiliki benda hibah atau pihak yang akan mewarisi benda hibah. Pelaksanaan pemberian hibah dianggap tidak sesuai dengan yang dikehendaki oleh si pemilik barang hibah atau ahli waris dari barang hibah tersebut karena bagian harta yang 
akan dihibahkan tidak boleh melebihi bagian ahli waris (Pasal 919 -929 KUHPerdata) atau saat perjanjian hibah perjanjian tersebut dianggap cacat hukum karena tidak memenuhi syarat-syarat perjanjian. Para pihak yang merasa dirugikan akan mengajukan tuntutan ke pengadilan yang berwenang untuk memperoleh kepastian hukum atas hak milik benda hibah tersebut.

Hal yang membuat penulis tertarik kasus tersebut untuk diangkat dalam tesis yaitu permasalahan-permasalahan hukum yang mungkin timbul atas hibah cacat hukum karena sifat hibah sebagai perjanjian sepihak adalah hibah tersebut diberikan kepada individu tanpa persetujuan ahli waris yang lain oleh pemberi hibah secara cuma-cuma kepada penerima hibah dengan menggunakan akta hibah yang telah disahkan oleh notaris,dan lain sebagainya. Dengan melihat latar belakang masalah tersebut, penulis tertarik untuk mengadakan suatu penelitian dengan judul "Cacat Hukum Dalam Hibah Sebagai Perjanjian Sepihak Dan

\section{Implikasinya"}

\section{B. Metode Penelitian}

Metode penelitian yang digunakan adalah yuridis empiris, dengan spesifikasi penelitiannya secara deskriptif analitis. Sumber dan jenis datanya berupa data primer dan data sekunder, lalu teknik pengumpulan data diperoleh melalui studi lapangan dan studi kepustakaan. Teknik analisa datanya menggunakan analisis kualitatif dengan pemikiran secara dedukatif-indukatif.

\section{Hasil dan Pembahasan}

\section{Akta Hibah Yang Cacat Hukum}

Menurut undang-undang, hibah adalah suatu perjanjian dimana si penghibah, di waktu hidupnya, dengan cuma-cuma dan dengan tidak dapat ditarik kembali, menyerahkan sesuatu benda guna keperluan si penerima hibah yang menerima penyerahan itu. Secara sederhana, hibah dapat diartikan sebagai pemberian sebagian atau seluruh dari harta kekayaan seseorang kepada orang lain sewaktu masih hidup dan peralihan hak dari pemberi hibah kepada penerima hibah sudah berlangsung seketika itu juga.(Suparman, 1995)

Dari bunyi Pasal 1666 KUHPerdata mengenai hibah terdapat katakata“tidak dapat ditarik kembali" ini tidak berarti bahwa penghibahan tidak dapat 
ditarik kembali oleh si penghibah dengan tiada izin pihak lain, oleh karena tiaptiap persetujuan hanya dapat ditarik kembali dengan kemauan kedua belah pihak (lihat Pasal 1338 ayat 2 KUHPerdata). Jadi hibah menurut Pasal tersebut hibah adalah perjanjian yang dilakukan oleh penghibah ketika masih hidup untuk memberikan suatu barang dengan cuma-cuma kepada penerima hibah.(Subekti, 1995)Hibah merupakan perbuatan hukum yang dilakukan atas kehendak yang ikhlas dari pemberi hibah. Dengan kata lain, inisiatif pemberian hibah berasal dari pemberi hibah dan bukan dari penerima hibah.

Pemberian itu tidak dapat ditarik kembali yang berarti dari ketentuan Pasal1666 KUHPerdata di atas, hibah disebutkan sebagai suatu persetujuan, yakni persetujuan yang terjadi antara si pemberi hibah dengan si penerima hibah, oleh karena itu hibah ditentukan oleh undang-undang sebagai suatu persetujuan, dengan sendirinya hibah itu menimbulkan suatu konsekuensi hukum; pemberi hibah wajib menyerahkan dan memindahkan barang yang dihibahkan kepada si penerima hibah.

Kompilasi Hukum Islam Buku II mengatur tentang hibah dari Pasal 171 sampai Pasal 214. Pengertian hibah adalah pemberian suatu benda secara sukarela tanpa imbalan dari seseorang kepada orang lain yang masih hidup untuk dimiliki. Setiap orang yang telah berumur sekurang-kurangnya 21 tahun, berakal sehat dan tak ada paksaan dapat menghibahkan sebanyak-banyaknya 1/3 (sepertiga) dari harta bendanya kepada orang lain atau suatu lembaga untuk dimiliki.(Abdul, 2006) Hibah harus dilakukan di hadapan dua orang saksi dan harta yang dihibahkan itu haruslah barang-barang milik pribadi (hak milik) orang yang memberi hibah.(Nasution, 1997)

Menurut Hukum Adat hibah adalah harta kekayaan seseorang yang dibagibagikannya di antara anak-anaknya pada waktu ia masih hidup. Penghibahan itu sering terjadi ketika anak-anak mulai berdiri sendiri atau ketika anak-anak mereka mulai menikah dan membentuk keluarga sendiri. Penghibahan itu dilakukan ketika si pemberi hibah itu masih hidup, dengan tujuan untuk menghindari percekcokan yang akan terjadi di antara anak-anaknya itu apabila ia telah meninggal dunia. Penghibahan itu terjadi kemungkinan juga sebagai akibat karena 
kekhawatiran si pemberi hibah sebab ibu dari anak-anaknya itu adalah ibu sambung atau ibu tiri, atau juga karena dikalangan anak-anaknya itu terdapat anak angkat yang mungkin disangkal keanggotaannya sebagai ahli waris.(Abdul, 2006)

Dari ketiga sumber hukum undang-undang, hukum adat dan Kompilasi Hukum Islam di atas dapat ditarik kesimpulan kalau hibah diatur pelaksanaanya oleh hukum, hibah dilakukan secara sepihak dan sukarela dan hanya dapat dilakukan apabila si penghibah masih hidup, dan ada syarat-syarat hukum yang mengatur pelaksanaan hibah. Di Indonesia hibah tidak diatur secara jelas oleh hukum adat. Beberapa suku masyarakat menggunakan hibah untuk menghindari aturan dan hokum tentang hibah dari Kompilasi Hukum Islam, sebagai contoh masyarakat Minangkabau menggunakan hibah untuk membagi harta kepada anakanak perempuannya yang secara adat merupakan penerus garis keturunan sedangkan kurang mendapatkan bagian waris menurut Hukum Islam atau hibah biasanya digunakan untuk membagi harta warisan kepada anak angkat yang tidak diakui haknya dalam warisan dalam Hukum Waris Islam. (Sabiq, 1985)

Kompilasi Hukum Islam Pasal 210 mengatur syarat pelaksanaan hibah yaitu:

a. Orang yang telah berumur sekurang-kurangnya 21 tahun berakal sehat tanpa adanya paksaan dapat menghibahkan sebanyak-banyaknya $1 / 3$ harta bendanya kepada orang lain atau lembaga di hadapan dua orang saksi untuk dimiliki;

b. Harta benda yang dihibahkan harus merupakan hak dari penghibah.

Menurut Kompilasi Hukum Islam hibah tidak dapat ditarik kembali dengan alasan apapun kecuali hibah yang diberikan oleh orangtua kepada anaknya (KHI Pasal 212) Hal ini sejalan dengan Hukum Islam sebagai sumber hukum dari hibah menurut Kompilasi Hukum Islam. Pelaksanaan Kompilasi Hukum Islam dimulai sejak Menteri Agama Republik Indonesia mengeluarkan Keputusan Nomor 154 Tahun 1991 sebagai pelaksana Impres Nomor 1 Tahun 1991 tentang Penyebarluasan Kompilasi Hukum Islam kepada seluruh instansi pemerintah dan masyarakat, baik melalui orientasi, penataran maupun dengan penyuluhan hukum.

Hal di atas berarti bahwa sejak tahun 1991 pelaksanaan hibah untuk masyarakat beragama Islam menggunakan hukum Kompilasi Hukum Islam. Hal 
ini membuka kemungkinan untuk hibah yang dilaksanakan sebelum tahun 1991 dapat dijadikan dasar untuk melakukan gugatan kepada Pengadilan Agama. Syarat pelaksanaan hibah yang sering menjadi dasar gugatan kepada pengadilan agama yaitu "Setiap orang yang telah berumur sekurang-kurangnya 21 tahun, berakal sehat dan tak ada paksaan dapat menghibahkan sebanyak-banyaknya 1/3 (sepertiga) dari harta bendanya kepada orang lain atau suatu lembaga untuk dimiliki."

Hal ini membuktikan bahwa perkara gugatan cacat hukum atas hibah umumnya dilakukan terhadap hibah yang melanggar syarat-syarat dan aturan pelaksanaan hibah baik menurut undang-undang maupun menurut Kompilasi Hukum Islam. Menurut undang-undang dan Kompilasi Hukum Islam, hibah tidak dapat dibatalkan atau ditarik kembali namun karena hibah adalah produk hukum, ditandai dengan adanya akta hibah yang diakui secara hukum maka dapat dilakukan gugatan cacat hukum hibah untuk membatalkan hibah melalui pengadilan.

Penulis dalam hal ini mengambil contoh Akta Hibah Nomor : 394/2011 oleh salah seorang PPAT di Kota Salatiga, Jawa Tengah dan Putusan Nomor: 236/Pdt.G/2010/PA.Pra oleh Pengadilan Agama Praya untuk dibahas. Kasus pertama bermula ketika Nyonya $X$, seorang pensiunan berusia 77 tahun menghibahkan sebidang tanah dan bangunan seluas 77 meter persegi kepada Nyonya Y. Nyonya X memiliki 8 orang anak kandung dimana Nyonya Y adalah salah satu anak kandungnya.

Untuk menghibahkan tanah dan bangunan tersebut kepada Nyonya Y, Nyonya X menghadap ke salah seorang PPAT di Kota Salatiga. Dalam proses pembuatan aktahibah oleh PPAT tersebut hanya melibatkan 2 pihak yaitu Nyonya $\mathrm{X}$ selaku pemberi hibah, untuk selanjutnya disebut pihak pertama dan Nyonya $\mathrm{Y}$ selaku penerima hibah, untuk selanjutnya disebut pihak kedua. Saksi yang turut menandatangani akta hibah ini adalah 2 orang staf PPAT tersebut. Bukti pendukung dalam akta hibah ini hanyalah Surat Keterangan Waris yang bertanda tangan ke delapan anak kandung Nyonya X, tanpa adanya Surat Pernyataan Hibah yang sepersetujuan dan bertanda tangan ke delapan ahli waris dari pemberi hibah. 
Pokok permasalahan dalam akta ini adalah: pertama, apakah akta hibah tersebut telah memenuhi syarat suatu akta otentik. Kedua, apakah surat keterangan waris dapat menggantikan posisi surat pernyataan hibah sebagai syarat pembuatan akta hibah.

Dalam kasus di atas, terdapat beberapa faktor yang dapat membuktikan bahwa hibah tersebut cacat hukum. Pertama, dalam hibah ini tidak perlu memakai surat keterangan waris dikarenakan sampai saat akta hibah ditandatangani, pemberi hibah yaitu Nyonya X masih hidup. Kedua, dasar penghibahan tersebut seharusnya adalah surat pernyataan hibah yang ditandatangani pemberi hibah dan ke delapan anak kandungnya yang tidak menerima hibah memberikan persetujuan. Hal ini supaya anak kandung yang lain tidak dirugikan dengan penghibahan ke salah satu anak tersebut. Sehingga akta hibah tersebut adalah cacat hukum.

Menurut penulis, persetujuan ahli waris lain yang tidak menerima hibah dalam wujud tanda tangan pada Surat Pernyataan Hibah adalah sesuatu yang harus ada. Hal ini mencerminkan nilai keadilan hukum bagi semua pihak. Menurut Radbruch, jika terjadi ketegangan antara nilai-nilai dasar tersebut, kita harus menggunakan dasar atau asas prioritas dimana prioritas pertama selalu jatuh pada nilai keadilan, baru nilai kegunaan atau kemanfaatan dan terakhir kepastian hukum.(Ali, 1996)

Meskipun akta hibah tersebut cacat hukum, namun karena dasar penghibahan adalah musyawarah mufakat kekeluargaan dan hingga tesis ini dibuat tidak ada gugatan terhadap akta hibah tersebut hingga proses balik nama ke penerima hibah oleh Badan Pertanahan Negara (BPN), maka penghibahan ini tidak menyebabkan masalah hukum hingga sekarang.

Berbeda dari kasus pertama, kasus kedua bermula ketika Tergugat mengajukan permohonan penerbitan sertipikat hak milik (SHM) atas nama Tergugat terhadap tanah sengketa yang dimiliki bersama antara Penggugat dengan Tergugat. Awal mulanya Para Penggugat berniat untuk mengurus sertipikat tanah sengketa tersbut ke Kantor Badan Pertanahan Nasional (BPN) Praya. Namun karena keterbatasan biaya niat tersebut ditangguhkan. Hal tersebut diketahui Tergugat lalu secara diam-diam Tergugat melakukan cara-cara guna memiliki 
tanah tersebut. Dengan memanipulasi data seolah-olah Tergugat menerima hibah dengan munculnya Surat Pernyataan Menerima Hibah dari Inaq Setip tanggal 26 Mei 2008 untuk tanah sengketa 1. Sedangkan untuk tanah sengketa 2 Tergugat memanipulasi Surat Pernyataan Pemberian Hibah tanggal 24 Pebruari 2007. Di pihak lain, Para Penggugat merasa tidak pernah menandatangani atau mencap jempol Surat Hibah tersebut.

Pokok masalah dalam perkara ini adalah: pertama, apakah Surat Pernyataan Hibah tertanggal 26 Mei 2008 dan Surat Pernyataan Pemberian Hibah tertanggal 24 Pebruari 2007 sah atau mempunyai kekuatan hukum. Kedua, apakah benar pada tanggal tersebut telah terjadi prosesi atau ijab-qobul hibah atas tanah sengketa dari Inaq Setip dan dari Penggugat 2 kepada Tergugat.

Dari permasalahan dan alat bukti yang diajukan Para Penggugat dan Tergugat, Majelis Hakim memberikan penilaian bahwa tanah sengketa tersebut sejak lama sudah dikuasai oleh para Penggugat. Penggugat 1 mengusai tanah seluas $\pm 4.300 \mathrm{M} 2$, Penggugat 2 mengusai tanah seluas $\pm 3.100 \mathrm{M} 2$. Orang tua Tergugat bernama Inaq Setip mengusasi tanah di sebelah selatan tanahnya Nuraman sampai ke gunung (sesuai gambar data pembagian tanah dari Kantor PBB Mataram tahun 1995) dan sekarang tanah bagian Inaq Setip tersebut dikuasai oleh Amaq Nasum. Terhadap pernyataan para saksi, Majelis Hakim berkesimpulan bahwa para saksi tidak pernah mengetahui adanya prosesi (ijabqobul) hibah terhadap obyek sengketa kepada Tergugat. Hanya, dari keterangan saksi Tergugat, yang ditunjukkan oleh Tergugat, saksi menyebut adanya surat pernyataan tetapi isinya tidak secara jelas saksi ketahui. Putusan Majelis Hakim dalam kasus ini yaitu membatalkan hibah terhadap Tergugat atas tanah sengketa tersebut.

Dalam kasus tersebut, terdapat beberapa faktor yang dapat membuktikan bahwa hibah tersebut cacat hukum. Pertama, dalam hal pengikatan hibah, berdasarkan Surat Pernyataan menerima hibah tertanggal 26 Mei 2008 dari orang tua Tergugat kepada Tergugat, pelaksanaan pengikatan hibah tersebut tidak sah karena orang tua Tergugat yang menghibahkan tersebut dapat dibuktikan meninggal dunia pada tahun 2005. Pasal 1666 KUHPerdata dengan jelas 
mengaskan bahwa "Hibah adalah suatu perjanjian dengan mana si penghibah, di waktu hidupnya, dengan cuma-cuma dan dengan tidak dapat ditarik kembali, menyerahkan sesuatu benda guna keperluan si penerima hibah yang menerima penyerahan itu."

Kedua, Terlihat jelas adanya kepalsuan materiil dalam Surat Pernyataan menerima hibah tanggal 26 Mei 2008 dan Surat Pernyataan Pemberian Hibah tanggal 24 Pebruari 2007, sehingga tidak dapat dijadikan dasar peralihan hak milik. Selain itu, karena hibah tersebut dilakukan di bawah tangan, maka dapat dilakukan pembatalan hibah, hal ini secara jelas diatur dalam Pasal 1688 KUHPerdata yang menjelaskan bahwa hibah tidak dapat dicabut atau dibatalkan, kecuali penerima hibah melakukan kesalahan-kesalahan seperti tersebut di bawah ini:

a) Tidak memenuhi syarat-syarat pemberian hibah yang berkenan

b) Tidak melakukan atau membantu melakukan usaha membunuh pemberi atau kejahatan lain terhadap pemberi hibah, dan

c) Menolak memberi tunjangan nafkah kepada pemberi hibah setelah disebut terakhir ini berada dalam keadaan miskin.

Pembatalan hibah dapat terjadi dimana salah satu penyebabnya adalah pemberian hibah tidak dilakukan sebagaimana yang disyaratkan, yaitu dilakukan dengan akta Notaris (Pasal 1682 jo 1683 KUHPerdata). Kecuali dalam hal pemberi hibah telah meninggal dunia dan ahli warisnya atau orang-orang yang mendapat hak dari si penghibah membenarkan adanya penghibahan atau mengesahkannya, maka tidak dapat lagi dikemukakan oleh mereka suatu cacat mengenai cara penghibahan yang ditentukan oleh undang-undang (Pasal 1894 KUHPerdata).

Berdasarkan Hukum Islam, pengertian hibah dalam Pasal 200 Kompilasi Hukum Islam adalah suatu perbuatan yang dilakukan dalam rangka penyerahan suatu barang / benda dari pemberi hibah kepada penerima hibah dan barang yang diserahkan tersebut adalah barang milik sendiri. Dalam kasus tersebut, Tergugat tidak dapat membuktikan kebenaran prosesi (ijab qobul) pelaksanaan hibah terhadap obyek sengketa. Dalam hal ini pertimbangan Majelis Hakim benar, 
karena selaras dengan pendapat ahli hukum terhadap Kitab Ianatut Thalibin jus III halaman 41yang artinya:

"Rukun hibah dalam pengertian khusus sama dengan rukun jual beli yaitu ada tiga: pemberi hibah, benda yang dihibahkan, dan ijab qobul."

Dan sesuai dengan dalil syar'I yang terdapat dalam Kitab Bajurijus II halaman 62 yang artinya:

"Tidak sah hibah kecuali dengan ijab dan qobul yang diucapkan."

Selain tidak dapat dibuktikannya kebenaran prosesi (ijab qobul) pelaksanaan hibah oleh Tergugat, dapat dibuktikan dalam fakta persidangan bahwa obyek sengketa sejak awal hingga sekarang masih tetap dikuasai oleh Para Penggugat dan Penggugat pula yang membayar pajaknya, sehingga tidak dipenuhinya unsur kepemilikan sendiri terhadap barang / obyek hibah.

\section{Implikasi Dari Akta Hibah Yang Cacat Hukum}

Hubungan hukum antara pemberi hibah dan penerima hibah adalah hubungan hukum karena adanya perjanjian dimana pemberi hibah sebagai debitor dan penerima hibah sebagai kreditor.(Widya, 2006)Hibah adalah hubungan hukum yang sepihak. Artinya, pemberi hibah memberikan hibah pada penerima hibah secara cuma-cuma tanpa ada imbalan apapun dari penerima hibah. Penerima hibah bisa berasal dari para waris/ waris itu sendiri.

Dengan adanya hibah, maka akan timbul hubungan hukum antara pemberi hibah dan penerima hibah walaupun hubungan hukum tersebut sifatnya sepihak yang artinya si pemberi hibah hanya punya kewajiban saja tanpa mempunyai hak, hendaknya dalam memberikan hibah pada seseorang dilihat terlebih dahulu kepatutan dan kepantasan dari si penerima hibah untuk menerima hibah tersebut, sehingga tidak timbul pembatalan hibah yang menyebabkan hubungan hukum antara kedua pihak bermasalah.

Akibat hukum adalah akibat-akibat yang ditimbulkan karena adanya suatu perbuatan, menurut aturan-aturan yang berlaku.Misalnya, kesepakatan dua belah pihak yang cakap, dapat mengakibatkan lahirnya perjanjian. Akibat hukum dapat terjadi pula karena terjadinya pembatalan suatu perbuatan hukum, misalnya adanya pembatalan hibah maka menimbulkan akibat hukum atas harta hibah. 
Akibat hukum bagi pihak internal atas pembatalan hibah yang dikabulkan di pengadilan dengan adanya putusan pembatalan hibah yang telah berkekuatan hukum tetap maka kepemilikan atas harta tersebut akan kembali kepada pemberi hibah. Dalam putusan Pegadilan Agama Praya di atas tanah sengketa 1 dan tanah sengketa 2 yang sudah proses pembuatan sertipikat di BPN Praya dikembalikan hak miliknya kepada Penggugat I dan Penggugat II. Para Penggugat dapat mengajukan permohonan kepada BPN agar sertipikat obyek sengketa tersebut tidak berlaku lagi dengan adanya putusan pembatalan hibah tersebut apabila proses pembuatan sertipikat telah selesai diproses oleh BPN. Dengan demikian sertipikat obyek sengketa tersebut tetap atas nama Para Penggugat.

Sedangkan bagi pihak Tergugat yang kalah dalam putusan ini, objek hibah yang telah diurus proses sertipikatnya menjadi atas nama Tergugat di BPN tidak dilanjutkan lagi prosesnya. Apabila Proses balik nama sertipikat sudah selesai diproses, maka atas sertipikat tersebut dinyatakan tidak berlaku lagi dengan adanya putusan pembatalan hibah tersebut. Sebagai pihak yang kalah, Tergugat dihukum untuk membayar biaya perkara sebagaimana telah diatur dalam Peraturan Mahkamah Agung No. 03 Tahun 2012 tentang Biaya Proses Penyelesaian Perkara dan Pengelolaannya Pada Mahkamah Agung dan Badan Peradilan yang Berada di Bawahnya.

Bagi pihak ketiga, bilamana dalam suatu keadaan penerima hibah menjual/memindahtangankan harta hibah kepada pihak lain dalam hal ini adalah pembeli tanah sengketa, Undang-undang tidak mengatur secara sistematis akibat dari kebatalan. Pada umumnya akibat dari suatu kebatalan adalah berlaku surut dan kembali pada keadaan semula atau ex tunc.Akibat hukum yang timbul dari harta hibah yang dimohonkan pembatalan pada pengadilan dengan adanya putusan pembatalan hibah yang telah berkekuatan tetap, maka kepemilikan atas harta hibah yang telah dijual/dipindahtangankan kepada pembeli tersebut akan kembali kepada pemberi hibah sehingga seluruh harta hibah akan kembali menjadi hak miliknya sendiri. Apabila objek hibah telah dibalik nama atau telah disertipikatkan atas nama pembeli, maka sertipikat tersebut dinyatakan tidak berlaku lagi. Pemberi hibah dapat mengajukan permohonan kepada BPN agar sertipikat objek 
sengketa tidak berlaku lagi dengan adanya putusan pembatalan hibah tersebut. Kemudian sertipikat objek sengketa dapat kembali diatasnamakan pemberi hibah.

Mengembalikan pada keadaan sebelum terjadi perbuatan hukum kadang tidak dapat dilakukan, dalam hal ini karena adanya cacat hukum dalam hibah dan bendanya telah dijual kepada orang lain. Ada kemungkinan nilai dari prestasi yang tidak dapat dikembalikan tersebut dikompensasikan dalam bentuk sejumlah uang. Yang kerap menjadi masalah mengenai penilaian tersebut ialah penentuan besarnya, dan memakai dasar penilaian pada waktu perjanjian dibuat atau pada waktu pembatalan dilakukan.(Budiono, 2012)

Menurut penulis, perlindungan hukum bagi pihak ketiga sebagai pemegang sertipikat hak milik terhadap penerbitan sertipikat yang cacat administrasi harus lebih dijamin oleh Pemerintah. Karena pihak ketiga sebagai pemegang sertipikat hak milik nyatanya telah melakukan jual beli sebidang tanah dari pihak kedua dan melakukan proses penerbitan sertipikat dengan prosedur yang sesuai.

\section{Simpulan}

Berikut ini merupakan kesimpulan Penulis dari beberapa permasalahan dalam penelitian ini, yaitu:

a. Hibah merupakan perbuatan hukum yang dilakukan atas kehendak yang ikhlas dari pemberi hibah. Dengan kata lain, inisiatif pemberian hibah berasal dari pemberi hibah dan bukan dari penerima hibah. Hanya si pemberi hibah saja yang dibebani dengan kewajiban-kewajiban, sedang penerima hibah, sama sekali tidak mempunyai kewajiban apa-apa. Di sinilah letak karakter hibah sebagai persetujuan yang sepihak dengan sifat cuma-cuma. Permasalahanpermasalahan hukum timbul atas hibah cacat hukum karena sifat hibah sebagai perjanjian sepihak. Perkara gugatan cacat hukum atas hibah umumnya dilakukan terhadap hibah yang melanggar syarat-syarat dan aturan pelaksanaan hibah baik menurut undang-undang maupun menurut Kompilasi Hukum Islam. Banyak gugatan kepada pengadilan agama untuk membatalkan hibah seperti 
salah satu kasus diatas yang gugatannya dikarenakan tanah yang dijadikan objek hibah bukanlah milik pemberi hibah dan pemberian hibah lebih besar dari besar hibah yang diatur oleh Kompilasi Hukum Islam yaitu 1/3 (sepertiga) dari harta bendanya, sehingga pelaksanaan hibah dinilai cacat hukum. Menurut undang-undang dan Kompilasi Hukum Islam, hibah tidak dapat dibatalkan atau ditarik kembali namun karena hibah adalah produk hukum, ditandai dengan adanya akta hibah yang diakui secara hukum maka dapat dilakukan gugatan cacat hukum hibah untuk membatalkan hibah melalui pengadilan.

b. Hibah, baik hibah yang dilaksanakan sesuai dengan hukum adat, hukum perdata atau undang-undang maupun Kompilasi Hukum Islam sangat mungkin untuk cacat hukum. Oleh karena itu ada akibat dan konsekuensi dari hibah apabila ternyata terbukti cacat hukum. Untuk Hibah yang cacat hukum karena telah melanggar ketentuan dan aturan hukum maka akibat dan konsekuensinya adalah hibah tersebut harus batal demi hukum sepanjang dapat dibuktikan telah melanggar aturan hukum.

\section{DAFTAR PUSTAKA}

Abdul, M. (2006). Aneka Masalah Hukum Perdata Islam Di Indonesia. Jakarta: Kencana Prenada Media Group.

Ali, A. (1996). Menguak Tabir Hukum. Jakarta: Chandra Pratama.

Amanat, A. (2003). Membagi Warisan Berdasarkan Pasal-Pasal Hukum Perdata BW. PT. Raja Grafindo Permai.

Budiono, H. (2012). Kumpulan Tulisan Hukum Perdata di Bidang Kenotariatan. Bandung: Citra Aditya Bakti.

Nasution, B. J. (1997). Hukum Perdata Islam, Kompetensi Peradilan Agama Tentang Perkawinan, Waris, Wasiat, Hibah, Wakaf dan Shodaqah. Bandung: Mandar Maju.

Sabiq, S. (1985). Pelaksanaan Hukum Waris dalam Lingkungan Minangkabau. Jakarta: Gunung Agung. 
Subekti, R. (1995). Aneka Perjanjian. Jakarta: PT. Citra Aditya Bakti.

Suparman, E. (1995). Intisari Hukum Waris Indonesia. Mandar Maju.

Widya, A. (2006). Tanggung Gugat Pemberi Hibah Akibat Pembatalan Hibah.

Universitas Surabaya, Surabaya. 